and trismus. As an acute presentation is unexpected therefore, clinical assessment in this case was difficult.

A diagnosis of salivary duct calculi should always be considered in children when there is submandibular swelling and the appearances are uncharacteristic of suppurating cervical nodes. In this way inappropriate exploration of the cervical swelling will be avoided.

I thank Professor R Y Calne for permission to report this case.

${ }^{1}$ Doku HC, Berkman M. Submaxillary salivary calculus in children. Am 7 Dis Child 1967;114:671-3.

${ }^{2}$ Feldman W. Submaxillary salivary calulus in a child. Can Med Ass $\mathfrak{f}$ 1970;102:1308.

s Longhurst P. Submandibular sialolithiasis in a child. Br Dent $\mathcal{F}$ 1973; $135: 291-2$.

4 Kaban LB, Mulliken JB, Murray JE. Sialadenitis in childhood. Am $\mathcal{f}$ Surg 1978;135:570-6.

${ }^{5}$ Bruns WT, Tang TT. Submandibular sialolithiasis in a cystic fibrosis patient. Am f Dis Child 1973;126:685-6.

(Accepted 1 March 1980)

University Department of Surgery, Addenbrooke's Hospital, Cambridge CB2 2 QQ

K NIGEL BULLOCK, MA, FRCS, registrar

\section{Porphyria cutanea tarda during maintenance haemodialysis}

Skin lesions indistinguishable from those of porphyria cutanea tarda occur in about $1 \%$ of patients on maintenance haemodialysis. ${ }^{1}$ Usually there is no evidence of abnormal porphyrin metabolism, ${ }^{1}$ but three cases in which true porphyria cutanea tarda developed during chronic haemodialysis have been reported. ${ }^{2}$ The primary enzyme defect is a decrease in hepatic uroporphyrinogen decarboxylase activity. $^{3}$ We describe a patient with an inherited defect of this enzyme who developed the condition while receiving chronic haemodialysis.

\section{Case report}

A 16-year-old boy with chronic glomerulonephritis was started on chronic haemodialysis in August 1975. In August 1976 he noticed hyperpigmentation, skin fragility, and multiple bullae on his face and backs of his hands. At this time urine output was very low and the diagnosis of porphyria cutanea tarda was established by measuring porphyrins in plasma (table) and faeces (isocoproporphyrin:coproporphyrin ratio 1.2 ; normal less than $0 \cdot 1)$. There was no family history of porphyria and no evidence of liver disease, and he was teetotal. Since August 1975 he had received aluminium hydroxide, methyldopa, propranolol, vitamin complex, iron-dextran $(100 \mathrm{mg}$ monthly), and six units of blood. From October 1976 dialysis was performed with a Haemodialyzer RP $6 \mathrm{HP}$ using an acrylonitrile membrane $\left(1.03 \mathrm{~m}^{2}\right.$; $30 \mu \mathrm{m}$ ), which reduced the plasma porphyrin concentration (table). The calculated dialysance for uroporphyrin was $79 \cdot 7 \mathrm{ml} / \mathrm{min}$. Skin fragility persisted and treatment with chloroquine ( $75 \mathrm{mg}$ weekly for two months), which worsened his hypertension, and cholestyramine was unsuccessful. In January 1979 serum ferritin was $878 \mu \mathrm{g} / \mathrm{l}$ (normal 10-250 $\mu \mathrm{g} / \mathrm{l}$ ).

The patient's uroporphyrinogen decarboxylase activity, measured in haemolysed whole blood after activation with dithiothreitol, using penta-

Porphyrin concentrations in plasma and dialysate in a patient who developed porphyria cutanea tarda during maintenance haemodialysis

\begin{tabular}{|c|c|c|c|c|}
\hline \multirow[b]{2}{*}{ Porphyrin } & & \multicolumn{2}{|c|}{ Plasma } & \multirow[b]{2}{*}{ Dialysate $\dagger$} \\
\hline & & $\begin{array}{c}\text { Before } \\
\text { haemodialysis }\end{array}$ & $\begin{array}{c}\text { After } \\
\text { haemodialysis }\end{array}$ & \\
\hline $\begin{array}{l}\text { Total porphyrin (nmol/1)* } \quad . \\
\text { Uroporphyrin }(\%) \\
\text { Heptacarboxylic porphyrin }(\%) \\
\text { Hexacarboxylic porphyrin }(\%) \\
\text { Pentacarboxylic porphyrin }(\%) \\
\text { Isocoproporphyrin }(\%) \\
\text { Coproporphyrin }(\%) \\
.\end{array}$ & $\begin{array}{l}\cdots \\
\because \\
\because \\
\because \\
\cdots\end{array}$ & $\begin{array}{r}1630 \\
61 \\
33 \\
6\end{array}$ & $\begin{array}{r}990 \\
61 \\
33 \\
6\end{array}$ & $\begin{array}{r}25 \\
54 \\
32 \\
7 \\
5 \\
<1 \\
1\end{array}$ \\
\hline
\end{tabular}

carboxylate porphyrinogen III as substrate, was $17 \cdot 2 \mathrm{pmol}$ coproporphyrin/ $\mathrm{min} / \mathrm{mg}$ haemoglobin (mean and range for 18 normal subjects: $24 \cdot 8,20 \cdot 3$ $32.6 \mathrm{pmol} / \mathrm{min} / \mathrm{mg}$ ). His sister and mother had similar low enzyme activities, 17.1 and $17.2 \mathrm{pmol} / \mathrm{min} / \mathrm{mg}$ respectively, whereas those of his brother $(35.6 \mathrm{pmol} / \mathrm{min} / \mathrm{mg})$ and father $(28.6 \mathrm{pmol} / \mathrm{min} / \mathrm{mg})$ were not low. Total urinary and faecal porphyrin excretion was normal in these relatives but his sister and mother showed increased urinary excretion of heptacarboxylic porphyrin, indicating subclinical porphyria cutanea tarda.

\section{Comment}

The occurrence of porphyria cutanea tarda during chronic haemodialysis for chronic renal failure is rare and the relation between these disorders is uncertain. In previous cases the cause of the uroporphyrinogen decarboxylase defect has not been determined. ${ }^{2}$ In our patient, as in a proportion of other patients with porphyria cutanea tarda ${ }^{4}$ it appears to have been caused by inheritance of an autosomal dominant gene, the effect of which is expressed in the liver as well as in red cells. ${ }^{3}$ The enzyme defect, therefore, must have been present before the onset of renal disease. Thus chronic haemodialysis, like alcoholic liver disease with siderosis, ${ }^{3}$ may be associated with porphyria cutanea tarda because it is capable of making an otherwise occult enzyme defect clinically manifest. Why haemodialysis should have this effect is not clear. The iron overload that is common in patients undergoing haemodialysis ${ }^{5}$ may be a factor in precipitating the disease. $^{2} 3$ Our patient received iron-dextran, and iron overload was certainly present after the onset of the porphyria. Alternatively, patients undergoing haemodialysis may produce or be subjected to compounds that affect hepatic haem synthesis.

Haemodialysis almost halved the concentration of porphyrins in the plasma of our patient, with nearly quantitative recovery in the dialysate and with little change in the porphyrin profile (table). In contrast, Poh-Fitzpatrick et al ${ }^{2}$ were unable to lower plasma porphyrins by haemodialysis. This difference may be explained by our use of a high-permeability membrane. Despite regular haemodialysis, plasma concentrations remained high, and effective treatment of porphyria cutanea tarda in these patients is difficult. Our patient reacted adversely to a low dosage of chloroquine and depletion of iron stores by repeated venesection cannot be justified.

${ }^{1}$ Brivet F, Drücke T, Guillemette J, Zingraff J, Crosnier J. Porphyria cutanea tarda-like syndrome in haemodialysed patients. Nephron $1978 ; 20: 258-66$.

2 Poh-Fitzpatrick MB, Bellet N, DeLeo VA, Grossman ME, Bickers DR. Porphyria cutanea tarda in two patients treated with haemodialysis for chronic renal failure. $N$ Engl f Med 1978;299:292-4.

${ }^{3}$ Kushner JP, Barbuto AJ, Lee GR. An inherited enzymatic defect in porphyria cutanea tarda: decreased uroporphyrinogen decarboxylase activity. $\mathcal{F}$ Clin Invest 1976;58:1089-97.

${ }^{4}$ De Verneuil H, Aitken G, Nordmann Y. Familial and sporadic porphyria cutanea: two different diseases. Hum Genet 1978;44:145-51.

$\checkmark$ Cotterill AM, Flather JN, Cattell WR, Barnett MD, Baker LRI. Serum ferritin concentration and oral iron treatment in patients on regular haemodialysis. $\mathrm{Br}$ Med $\mathcal{F}$ 1979; ; 790 .

(Accepted 8 February 1980)

Department of Nephrology, 1st Octubre Hospital, Madrid, Spain

J GARCIA PARRILLA, resident in medicine

$R$ ORTEGA, resident in medicine

$M$ L PENA, resident in medicine

J L RODICIO, MD, consultant and head of renal unit

Department of Internal Medicine (Professor Gilsanz), School of Medicine, Madrid, Spain

R E DE SALAMANCA, MD, consultant physician

A OLMOS, medical student

Department of Medical Biochemistry, Welsh National School of Medicine, Cardiff CF4 4XN

G H ELDER, MD, MRCPATH, professor

\section{Correction}

Alpha-chain disease diagnosed by rectal biopsy

In the short report by Dr J M Rhodes et al (12 April, p 1043) the antiserum is stated to have been supplied by Mercia Diagnostics. This has now amalgamated with Brocades (GB) Ltd and for the last two years has been trading under the name of Mercia-Brocades L.td. 